\title{
Optimization and Performance Analysis of Residential Building for Sustainable Energy Design Through BIM
}

DOI:10.36909/jer.ACMM.16297

\author{
G. NAKKEERAN, L. KRISHNARAJ* \\ Research Scholar, *Assistant Professor \\ Department of Civil Engineering, SRM Institute of Science and Technology, Kattankulathur, \\ Tamil Nadu, India-603203. \\ *Corresponding author: krishnal@ srmist.edu.in
}

\begin{abstract}
The problems and effects of global warming stand a primary concern for most of the people in today's world. As the demand for energy increases, the available energy resources noticeably decrease which rapidly upsurges the need for energy-efficient buildings. Housing is one of the largest energy consumers as it consumes about $40 \%$ of the total energy. This study aims to improve the energy consumption and the strength of houses in India compared to other materials in construction walls. The study includes the record of electricity life cycle, fuel consumption and Life Cycle Energy Costs (LCEC), the intensity of the annual energy consumption and the peak value of the annual demand, its evaluation and presents the comparison with the original planning. Finally, the measure of the total annual energy and total electricity and fuel life cycle costs for the building wall in the Indian scenario using sustainable energy efficient design and construction methods under BIM and tools like Revit, Insight360 and Green Building Studio are presented. An energy analysis model that integrates BIM to create precise residential performance forecasts with better optimization scenarios is represented.
\end{abstract}

Keywords: BIM, energy analysis, total life cycle cost, Green Building Studio, Revit. 


\section{INTRODUCTION}

The construction industry contributes significantly to the social and economic development of the country. It consumes most of the available energy and natural resources. Globally, 30-40\% of the primary energy sources, consumed by buildings, accounting for $40-50 \%$ of global warmingrelated gas emissions. Consequently, the construction industry must realize the sustainable development of society. Sustainable development is considered to be a development with low environmental impact and high economic and social benefits. Professional architects and engineers are more concerned with the sustainability and energy efficiency of the proposed building. Analyzing a building's life cycle at the beginning of the design process would be very useful for designers to opt for alternative designs that would lead to more energy-efficient installations.

Building energy simulation helps build models that analyze energy movement indoors, outdoors, and across rooms and volumes. An entire building's energy analysis or simulation measures the expected energy consumption (in terms of fuel and electricity) calculative of building's shape, its type, climatic condition, cladding properties, and active systems such as heating and ventilation (Soegoto 2021) and lighting. This information helps designers better analyze and render decisions that improve the building's performance and reduce the building's environmental impact.

The study thus examines the energy efficiency of a residential building in Chennai, Tamil Nadu, India. The reseachers, therby are investigating a method to improve thermal comfort by quantitatively analyzing the thermal effect of the outer skin. Environmental and energy efficiency in buildings can be enhanced using Revit and Insight 360. Current workflows such as Revit energy analysis are brought into the Revit model with Insight 360. Building and wall 
design optimization has been summarised in this study based on simulation results for lifecycle costs and annual energy consumption.

\section{REVIEW OF ENERGY ANALYSIS}

Buildings use direct and indirect energy in all phases of life. The electrical energy used in building constructions is defined as energy(Abotalib et al. 2021). A building's operating energy is the required energy needed to keep the building comfortable and operational constantly. Heating, ventilation, air condition (HVAC), and other appliances are included in this energy category. A building's energy use can be categorised as "visible energy" and "work-energy." Weather conditions and executive plans vary widely depending on the level of comfort desired(M. Suliman and A. Elsheikh 2021).

A few research papers have pointed ways to calculate energy consumption during the life cycle. The stipulation is that $85 \%$ of the total energy consumption is required in the operational phase, and $15 \%$ is required for the renewable stage. The energy transfer utilised in dismantling structures and processes requires only $1 \%$ of the total energy. Energy consumption operates in its life cycle are of (80-90) and (10-20) years and represents the energy of a building. The expected energy consumption corresponds to a typical residential life cycle. It ranges from 150 to $400 \mathrm{kWh}$ (primary) and 250 to $550 \mathrm{kWh} / \mathrm{sq} \mathrm{m}$ (primary) per square meter of building per year. It has also been proposed to reduce operational efficiencies, thus reducing the energy required throughout the life cycle.

(Crafford, Wessels, and Blumentritt 2018) Climate-controlled northern industrialised countries have been used as the primary source of data in developing LCA-based assessment tools for green building. A focus on the operational energy requirements of buildings may lead to an 
exaggeration of both the monetary value and the practical significance of the materials used in their construction. (Ajayi, Oyedele, and Ilori 2019)This study examines the vitality of changes in the embodied carbon during the entire life cycle of complete buildings. Life cycle analysis method examined the effects of material and renewable energy properties on the visualized and operational effects. Revit was used to design an office building case study and to perform a sensitivity analysis for a typical building by changing material properties and energy consumption pattern of seven other models.

(Palme, Privitera, and la Rosa 2020)It has been shown that energy savings were achieved when the building facade was completely shaded. The range of cooling load reduction for buildings is observed to be between $2 \%$ and $50 \%$ depending on the type and configuration. In half of the 41 configurations examined, an average reduction of $15 \%$ was achieved. Current modelling techniques for performance analysis have some limitations such as lack of transparency in modelling algorithms. limited evidence that interactions between residents and qualitative data cannot be assimilated. A few research has pointed out that BIM also provides good static design. It is also helpful for iteration, analysis, and building design optimization. They have also concluded that the expansion of scanning tools is due to the growing importance of sustainable design in construction and in improving construction performance. Therefore, it can be supposed that it is ideal for showing a BIM-based design style in all studies in the literature. Information that can be used to improve construction design and performance.

\section{BIM IN ENERGY STRATEGY}

BIM Energy examination tools predict the thermal comfort of occupants and energy efficiency of buildings. The analysis allows in determining building performance based on specific criteria and comparing different design options. The data required for analysis of the structures are 1) 
building architecture, including room planning and design 2) information on the thermal properties of materials and components used in construction 3) orientation of the building and current weather data for the area where the property is located.

\section{ANALYSIS WORKFLOW}

Revit Architecture 2020 was used to model an actual residential structure. A 3D model of the building was shaped to show the various parts of the building. A case study involved an actual residential construction in Chennai, Tamil Nadu, India. The building model built using Revit was used for analysis in Revit. To begin with, step in energy simulation is to determine the purpose of the energy Figure 1. The proposed goals are: 1.) to compile all relevant drawings and data on the building under consideration. 2.) create a three-dimensional model using Autodesk Revit 3.) to analyze and run results in the Inside 360 software.4.) to estimate the energy use of the building
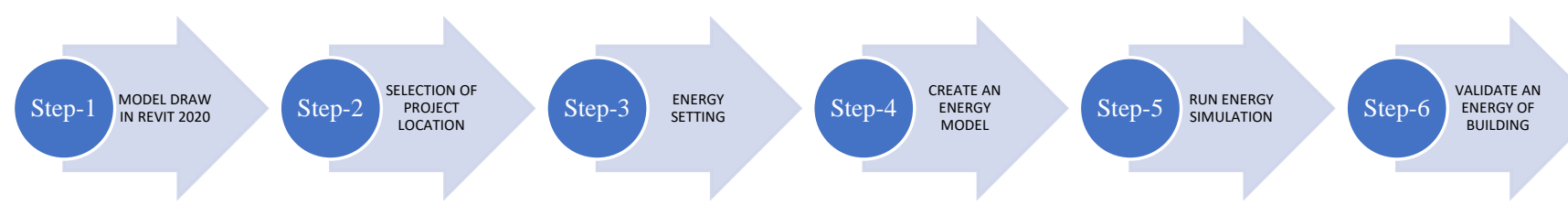

FIGURE 1. Work Flow

\section{REVIT}

(Krishnaraj et al. 2017; Krishnaraj et al. 2021) Revit is used in the 3D modeling method to provide a comprehensive platform for building information models. Architectural elements such as walls, ceilings, windows, and floors were created as 3D models in Revit. Revit also a feature of Revit, which uses virtual shapes to model shape and orientation early in design. This 
completes the flow modeling. In addition to architectural modeling, Revit also offers tools for mechanical engineering, electrical and sanitary engineering (MEP) and structural planning.

\section{Auto CAD INSIDE}

Fast, intuitive, and results-based guides improve building and environmental performance throughout the building lifecycle. Visualization and manipulation of key performance indicators, parameters, factors, domains, and specifications with cause-and-effect feedback in real-time aid in optimal results. Modeling with Form It Pro and Revit allows to generate robust, automated analysis models and visualize performance information in the modeling environment to gain insight. State-of-the-art simulation engine are employed for fully simulating buildings in the energy, heating, cooling, solar and solar sectors. Innovative cloud technology showed millions of possible outcomes simultaneously.

\section{GREEN BUILDING STUDIO}

Comprehensive performance analysis tool for construction with Autodesk products is Revit2020. Using Green Building Studio, any building can run an energy analysis to understand how it compares to other structures. BIM-based energy and sustainability analysis is performed using the DOE-2 simulation engine. An identical user interface and a readable output of the generated data distinguish DOE 2, a BMS backup. DOE 2 Programs that can export gbXML will also work with GBS because they can parse gbXML files. It depends on the external data source. GBS requires an Autodesk subscription for full functionality and works only with the Autodesk registry. Still, some settings cannot be changed in the software. Due to the fact that it is hosted in the cloud, local installation is not an option. The data can be accessed anywhere with an internet connection, as an added benefit. 


\section{BUILDING DESIGN AND DESCRIPTION}

The Residential building to be built is located in Chennai, India. It is a double-story building with a height of $10 \mathrm{~m}$ and a design area of $6,151 \mathrm{ft}^{2}$ for the air conditioning and heating system. This building is in a true north-facing.

\section{CREATE ENERGY MODEL}

Design a building with a materials specification in Revit software and create space of building shown in figure 2. In energy, creates an energy model.

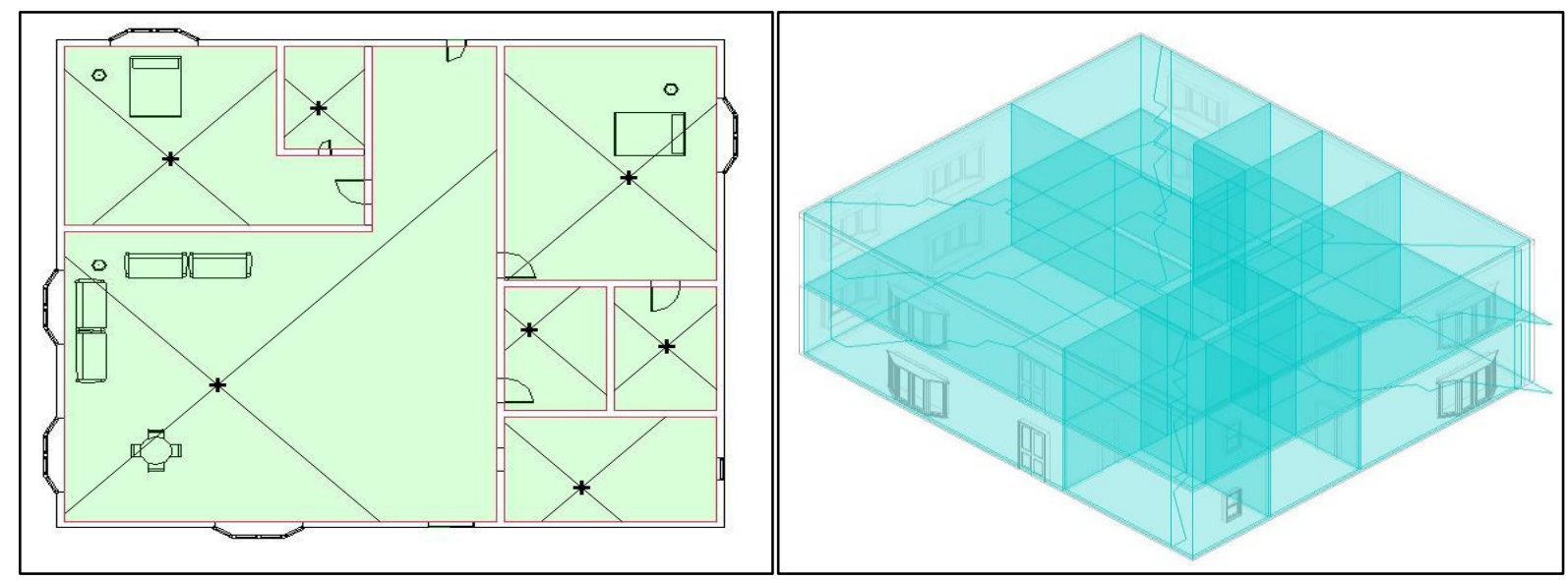

FIGURE 2. Space Model and Energy Model

\section{RESULTS AND INTERPRETATION}

An energy model is run in an optimization tool insight of Revit energy analysis show the results of an existing building's Maximum energy consumption of energy cost, EUI, and The Benchmark of Energy cost as shown in figure 3. 

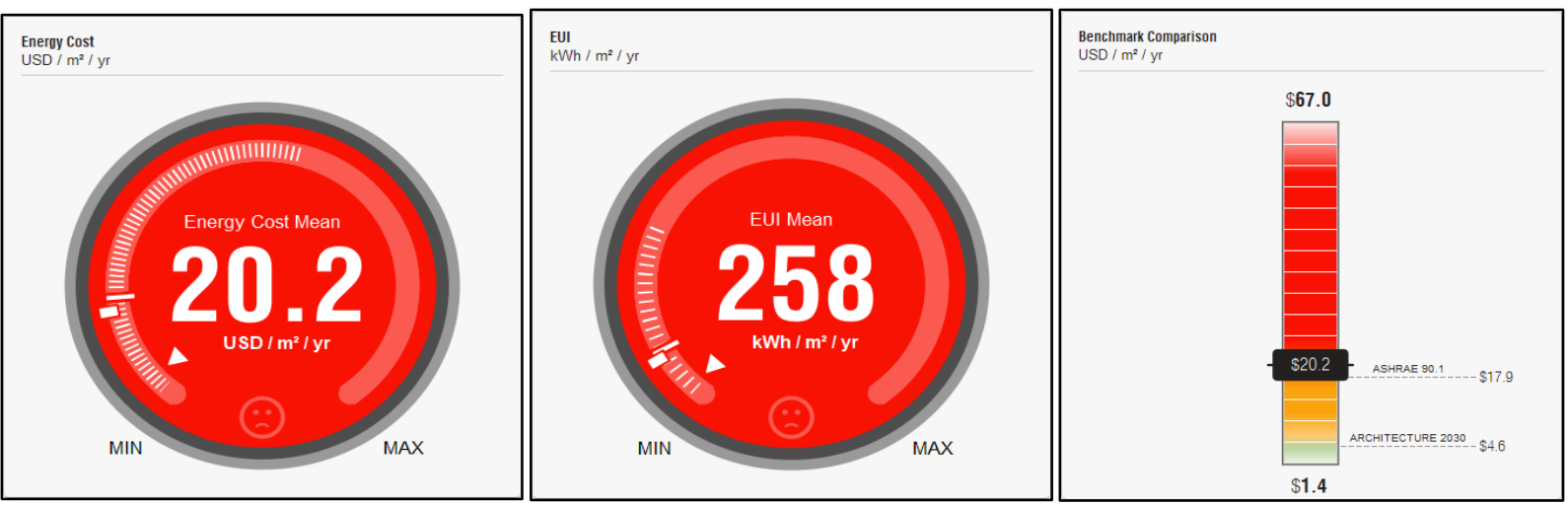

FIGURE 3. Initial Energy Analysis-Maximum Energy and Cost

Optimization of building with an alternative best scenario is The Energy Use Intensity (EUI) was $258 \mathrm{kWh} / \mathrm{m} 2 /$ year before the changes were applied in the design. EUI was reduced to 204 $\mathrm{kWh} / \mathrm{m} 2 /$ year after using materials recommended by Autodesk Insight. Thus, the scope of any design scenario can be altered to reduce the energy consumption of the building.
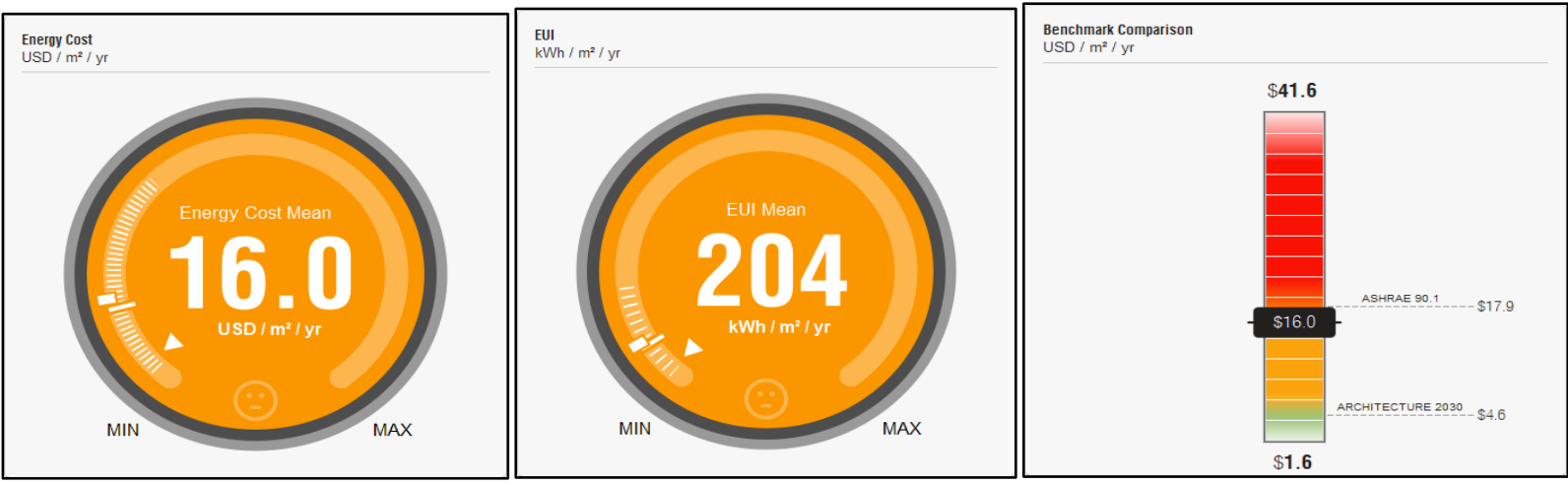

FIGURE 4. Optimized Energy Analysis-Minimum Energy and Cost

An energy model is run in an optimization tool insight of Revit energy analysis. The results present Alternative building Minimum energy consumption of energy cost, EUI, and The Benchmark of Energy cost in figure 4. 
(Maurya et al. 2021)Before employing the changes to the design features, the Energy Cost value was $20.2 \mathrm{USD} / \mathrm{m} 2 / \mathrm{yr}$. The Energy Cost value was reduced to $16 \mathrm{USD} / \mathrm{m} 2 / \mathrm{yr}$ after using the materials recommended by Autodesk Insight.

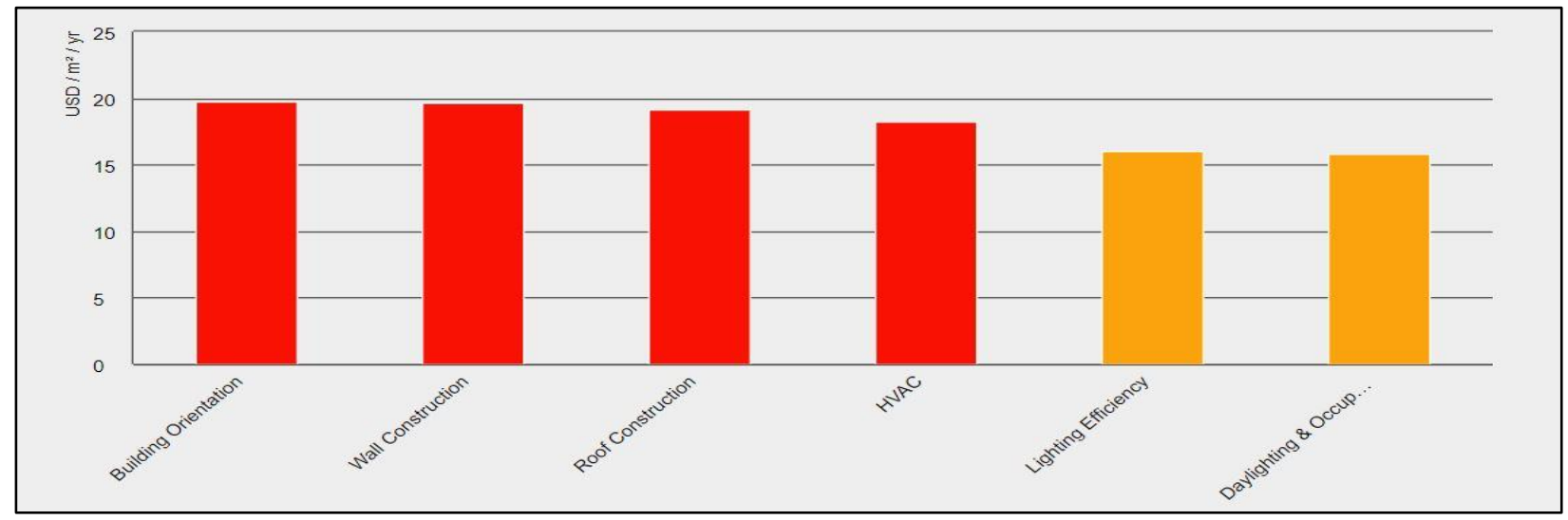

FIGURE 5. Optimized Energy Analysis with A Different Scenario

Figure 5 demonstrates an alternative of optimized energy analysis in EUI and Cost of roof construction, Building Orientation, Wall Construction, Daylighting and Occupancy Controls, and Lighting Efficiency (Liu et al. 2021). Analysis made with different scenarios for optimizing a EUI from the other results is depicted in Figure 6. The cost optimization results chart is shown in figure 7.

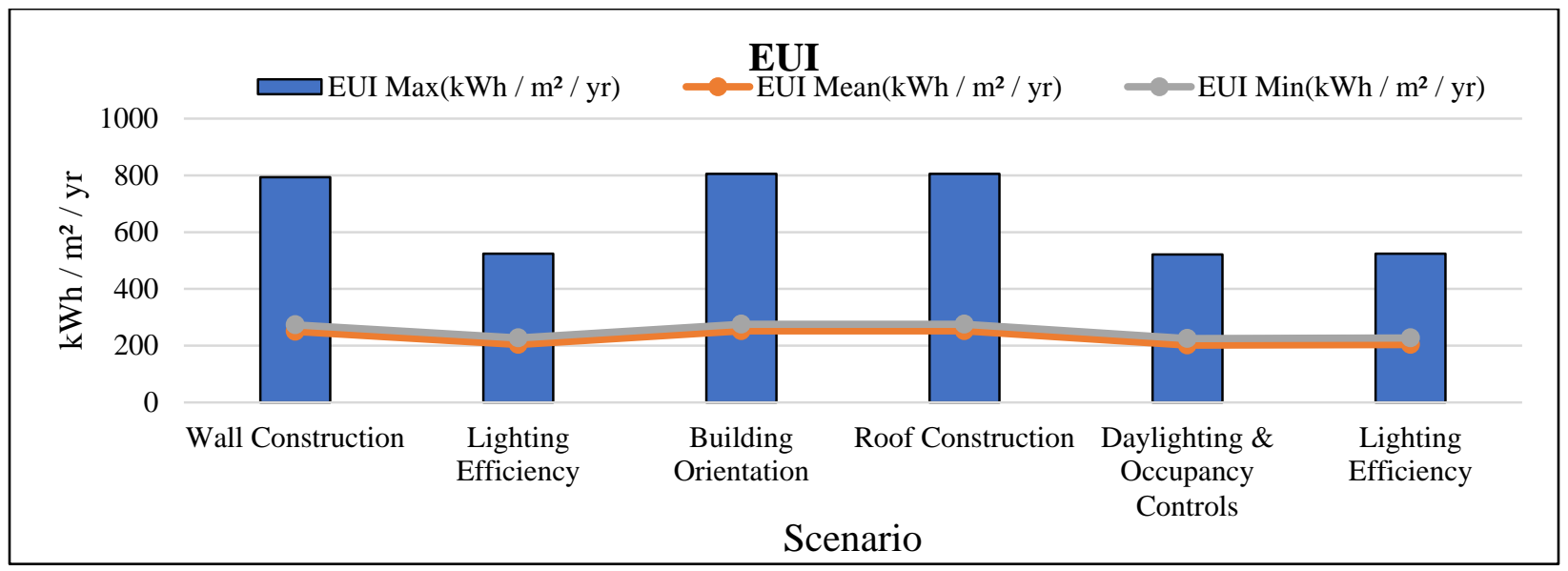

FIGURE 6. Optimized Energy Analysis-EUI 


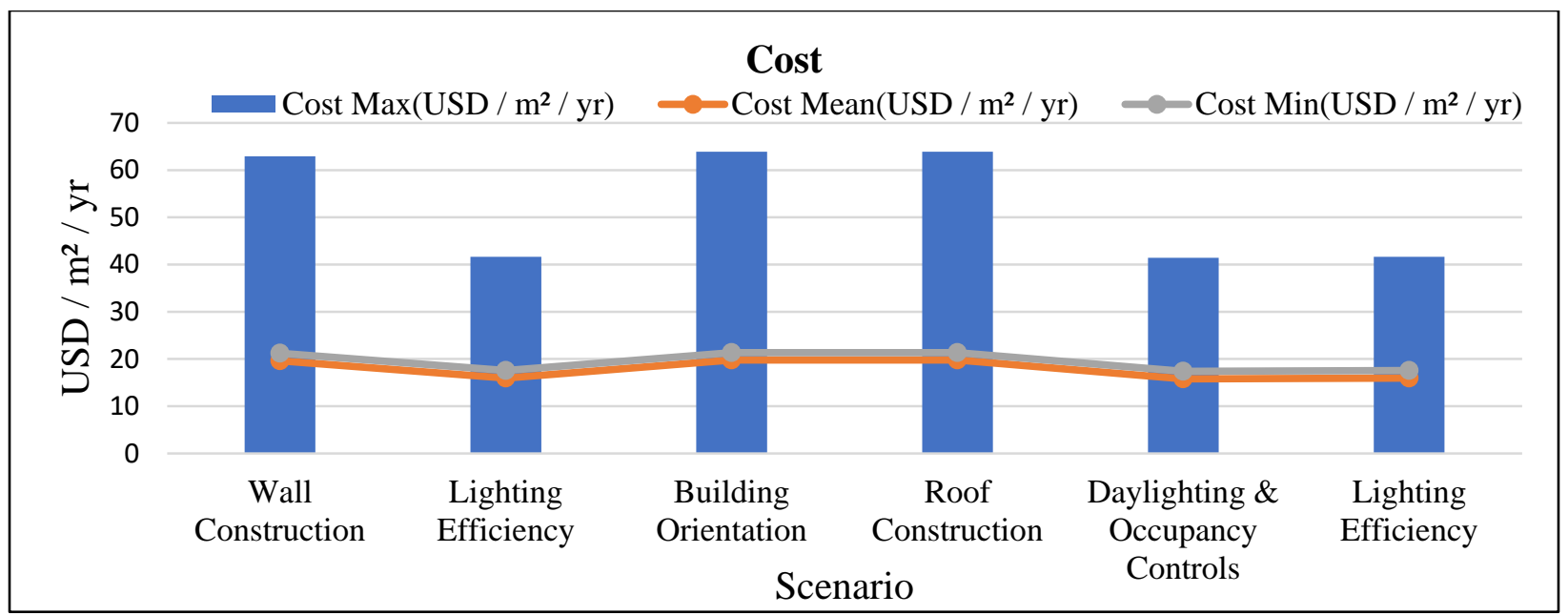

FIGURE 7. Optimized Energy Analysis-Cost

\section{ENERGY CONSUMPTION AND COST}

In addition, In Green Building Studio, create a project and run a model with an initial design and a alternative design in a wall design using the energy model. To calulate an Annual Energy Electric,Annual Energy Fuel,Lifecycle Energy Electric,Lifecycle Energy Fuel, Lifecycle Energy Cost, Annual Peak Demand, Energy Use Intensity (EUI).

Table 1. Cost, Energy, and EUI

\begin{tabular}{|c|c|c|c|c|c|c|c|}
\hline $\begin{array}{c}\text { Building } \\
\text { Design }\end{array}$ & $\begin{array}{c}\text { Annual } \\
\text { Energy } \\
\text { Electric } \\
(\mathbf{k W h})\end{array}$ & $\begin{array}{c}\text { Annual } \\
\text { Energy } \\
\text { Fuel } \\
(\mathbf{k W h})\end{array}$ & $\begin{array}{c}\text { Lifecycle } \\
\text { Energy } \\
\text { Electric } \\
(\mathbf{k W})\end{array}$ & $\begin{array}{c}\text { Lifecycle } \\
\text { Energy } \\
\text { Fuel }\end{array}$ & $\begin{array}{c}\text { Lifecycle } \\
\text { Energy } \\
\text { Cost }\end{array}$ & $\begin{array}{c}\text { Annual } \\
\text { Peak } \\
\text { Demand } \\
(\mathrm{kW})\end{array}$ & $\begin{array}{c}\text { Energy } \\
\text { Use } \\
\text { Intensity } \\
\text { (EUI) } \\
\text { (kBtu / } \\
\text { ft }^{2} / \\
\text { year) }\end{array}$ \\
\hline $\begin{array}{l}\text { Initial } \\
\text { Design }\end{array}$ & 111,357 & 3340.2 & $3,340,704$ & 100528.7 & $\$ 122,555$ & $29.6 \mathrm{~kW}$ & 64 \\
\hline
\end{tabular}


According to energy analysis result the table-1 showed the energy use intensity for electricity is $17 \mathrm{kWh} / \mathrm{sf} /$ year and fuel is $2 \mathrm{kBtu} / \mathrm{sf} /$ year. As a whole, energy use intensity is 59 $\mathrm{kBtu} / \mathrm{sf} /$ year. $(1 \mathrm{kWh}=3.14 \mathrm{kBtu})$. According to energy analysis result the table-4 showed the energy use intensity for electricity is $17 \mathrm{kWh} \mathrm{/} \mathrm{sf} /$ year and fuel is $2 \mathrm{kBtu} / \mathrm{sf} /$ year. As a whole, energy use intensity is $59 \mathrm{kBtu} / \mathrm{sf} /$ year. $(1 \mathrm{kWh}=3.14 \mathrm{kBtu})$. Life cycle energy use/cost the following table-5 executed the total life cycle energy cost is about $\$ 80,555$. Life cycle time period is considered by the tool is about 30 years

\section{ANALYSIS ENERGY CONSUMPTION AND LIFE CYCLE COST}

(Alothman, Ashour, and Krishnaraj 2021)The validation of a building is based on its life-cycle energy consumption and the annual cost of the energy. Electricity and fuel use intensity and annual energy and cost are taken into account during these calculations. For electricity, it is $111,357 \mathrm{kWh} / \mathrm{ft} 2 / \mathrm{year}$, and for fuel, it is 114 therms/year. This results in an overall energy use intensity (EUEI) of $64.4 \mathrm{kBtu} / \mathrm{ft} 2 / \mathrm{year}$. (A kilowatt-hour is equal to 3.14 kilocalories). It took about $\$ 122,555$ in total energy to complete the following life cycle electricity use/cost calculation. A period of 30 years were taken into account by the tool to calculate the life expectancy.

\section{LIFE CYCLE COST AND ANNUAL ENERGY COST OF WALL ALTERNATIVE}

(Jalaei and Jrade 2014)According to Green Building Studio recommendations, eight alternative wall components were analysed to see how they stack up against the original design. These included Uninsulated CMU, Insulated Concrete Form (ICF), R13 Metal, etc. As an alternative component, alternative wall analysis details, including annual and life-cycle costs are shown in Table 2. Figure 8 shows that uninsulated, R38 Wood and CMU wall construction has the highest 
life cycle energy use and cost values among the other options, and Wall Construction_12.25-inch SIP,14-inch ICF Wall Construction has the highest life cycle energy use and cost values.

Table 2. Estimated Energy and Cost Summary

\begin{tabular}{|c|c|c|c|c|c|c|}
\hline $\begin{array}{l}\text { Wall Alternative } \\
\text { Materials }\end{array}$ & $\begin{array}{c}\text { Annual } \\
\text { Energy } \\
\text { Cost } \\
(\$)\end{array}$ & $\begin{array}{l}\text { Lifecycle } \\
\text { Cost } \\
(\$)\end{array}$ & $\begin{array}{c}\text { Energy } \\
\text { Use } \\
\text { Intensity } \\
\text { (EUI) } \\
\text { (kBtu / ft² } \\
\text { / year) }\end{array}$ & $\begin{array}{c}\text { Annual } \\
\text { Energy } \\
\text { Electric } \\
(\mathbf{k W h})\end{array}$ & $\begin{array}{c}\text { Annual } \\
\text { Energy } \\
\text { Fuel } \\
\text { (Therms) }\end{array}$ & $\begin{array}{l}\text { Annual } \\
\text { Peak } \\
\text { Demand } \\
(\mathbf{k W})\end{array}$ \\
\hline $\begin{array}{l}\text { Wall Construction } \\
\text { Uninsulated }\end{array}$ & 9,320 & 126,939 & 66 & 115,380 & 114 & 30.5 \\
\hline $\begin{array}{l}\text { Wall Construction_R13 } \\
\text { Metal }\end{array}$ & 9,087 & 123,758 & 64 & 112,461 & 114 & 29.7 \\
\hline $\begin{array}{l}\text { Wall Construction_R13 } \\
\text { Wood }\end{array}$ & 9,008 & 122,693 & 64 & 111,484 & 114 & 29.7 \\
\hline $\begin{array}{l}\text { Wall Construction } \\
\text { R13+R10 Metal }\end{array}$ & 8,909 & 121,344 & 63 & 110,245 & 114 & 29.3 \\
\hline $\begin{array}{l}\text { Wall Construction_14- } \\
\text { inch ICF }\end{array}$ & 8,871 & 120,826 & 63 & 109,769 & 114 & 29.2 \\
\hline $\begin{array}{l}\text { Wall Construction_R38 } \\
\text { Wood }\end{array}$ & 8,881 & 120,954 & 63 & 109,888 & 114 & 29.2 \\
\hline $\begin{array}{l}\text { Wall Construction_R2 } \\
\text { CMU }\end{array}$ & 9,094 & 123,857 & 64 & 112,552 & 114 & 29.6 \\
\hline $\begin{array}{l}\text { Wall } \\
\text { Construction_12.25-inch } \\
\text { SIP }\end{array}$ & 8,879 & 120,928 & 63 & 109,864 & 114 & 29.2 \\
\hline
\end{tabular}




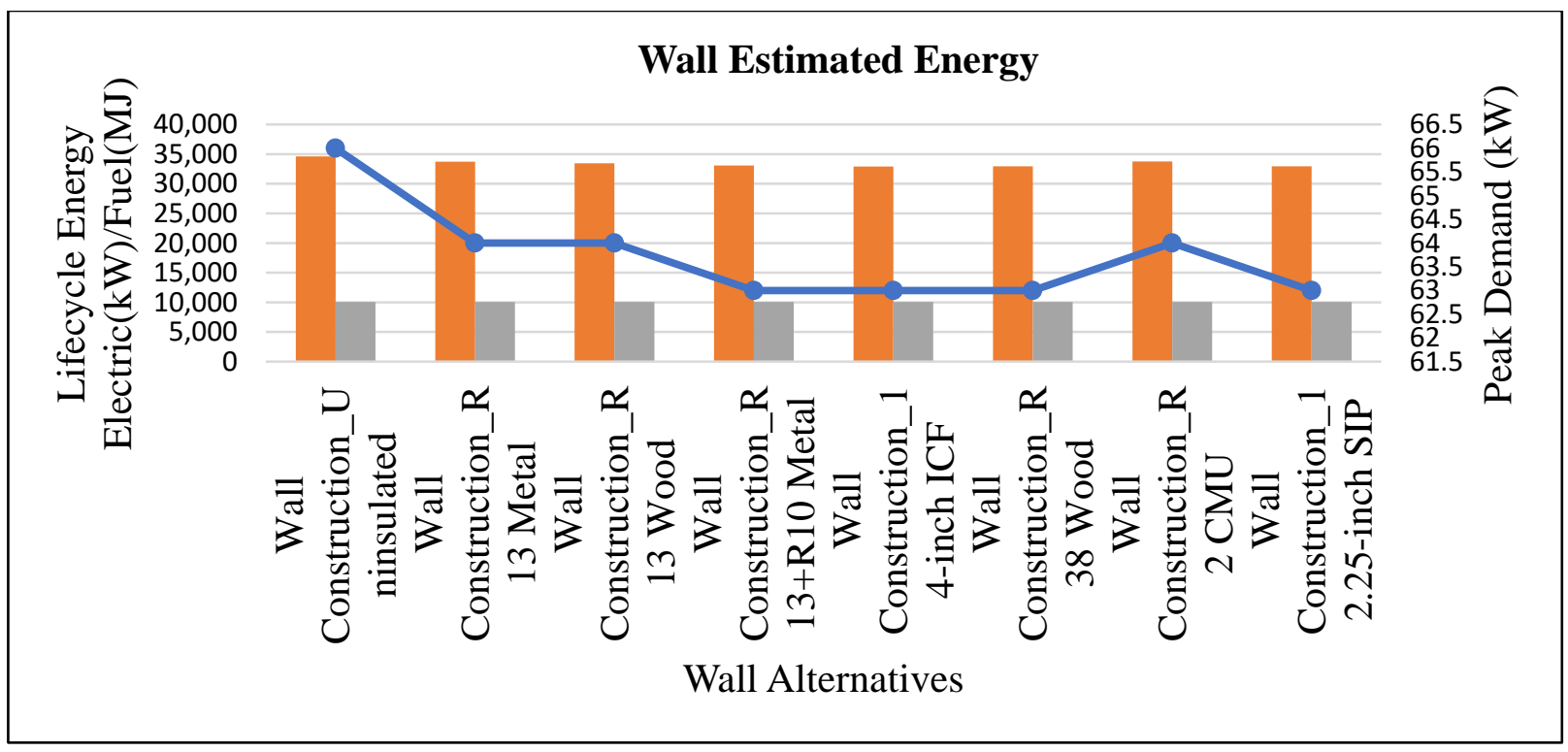

FIGURE 8. Life Cycle Cost and EUI

Table 3. Comparison on Annual Energy \& Life cycle cost

\begin{tabular}{|c|c|c|c|c|c|c|c|}
\hline $\begin{array}{c}\text { Building } \\
\text { design }\end{array}$ & $\begin{array}{c}\text { Annual } \\
\text { Energy } \\
\text { Electric } \\
\mathbf{( k W h )}\end{array}$ & $\begin{array}{c}\text { Annual } \\
\text { Energy } \\
\text { Fuel } \\
\mathbf{( k W h )}\end{array}$ & $\begin{array}{c}\text { Lifecycle } \\
\text { Energy } \\
\text { Electric } \\
\mathbf{( k W )}\end{array}$ & $\begin{array}{c}\text { Lifecycle } \\
\text { Energy } \\
\text { Fuel }\end{array}$ & $\begin{array}{c}\text { Lifecycle } \\
\text { Energy } \\
\mathbf{C o s t} \\
\mathbf{( \$ )}\end{array}$ & $\begin{array}{c}\text { Annual } \\
\text { Peak } \\
\text { Demand } \\
\mathbf{( k W )}\end{array}$ & $\begin{array}{c}\text { Energy Use } \\
\text { Intensity } \\
\mathbf{( E U I )} \\
\mathbf{( k B t u} / \mathbf{f t}^{2} / \\
\mathbf{y e a r})\end{array}$ \\
\hline $\begin{array}{c}\text { Initial } \\
\text { design }\end{array}$ & 111,357 & 3340.2 & $3,340,704$ & 100529 & 122,555 & 29.6 & 64 \\
\hline $\begin{array}{c}\text { Alternative } \\
\text { design }\end{array}$ & 109,769 & 3340.2 & $3,293,082$ & 3,431 & 120826 & 29.2 & 63 \\
\hline
\end{tabular}

\section{MAJOR FINDING}

Energy efficiency and building component costs are examined in this study using Green Building

Studio. The energy and cost analysis of the recommended parameters is compared to the standard design as shown in table 3 depending on the previous evaluation process for each 
building parameter. Building a wall of 14-inch ICF combination is understood to be the best option for a wall's performance.

\section{CONCLUSION}

To conclude, the model can be analyzed automatically and allows a simple study of alternative solutions to be discussed directly through this BIM collaborative environment. The findings are

Autodesk Revit 2020 can be used in assessing the building's energy efficiency and cost using BIM techniques.

$>$ Green Building Studio takes into account the various external parameters and internal building components such as a wall.

The energy consumption of the residential building special results can be interpreted in life cycle cost and annual energy cost of wall.

The results have shown that the parameters increase the wall's energy efficiency and meet the building sustainability objectives of environmental, financial, and social benefits.

Buildings in the future can be constructed using a variety of building materials, locations, and energy sources.

\section{REFERENCE}

Abhinaya, K. S., V. R. Prasath Kumar, and L. Krishnaraj. 2017. "Assessment and Remodelling of a Conventional Building into a Green Building Using BIM.” International Journal of Renewable Energy Research 7 (4): 1675-81.

Abotalib, Mohammad, Jaya Jacob, Hamid Alhamadi, and Dhary Alkandari. 2021. "The Environmental Cost and Benefits Analysis of Different Electricity Options: A Case Study of Kuwait." Journal of Engineering Research 9 (2): 308-19. 
Ajayi, Saheed O., Lukumon O. Oyedele, and Olusegun M. Ilori. 2019. "Changing Significance of Embodied Energy: A Comparative Study of Material Specifications and Building Energy Sources.” Journal of Building Engineering 23 (May): 324-33.

Alothman, Ahmad, Shimaa Ashour, and L. Krishnaraj. 2021. "Energy Performance Analysis of Building for Sustainable Design Using Bim: A Case Study on Institute Building." International Journal of Renewable Energy Research 11 (2): 556-65.

Herman Soegoto. 2021. "Green Building Concept Application with VRF Air Conditioning System." Journal of Engineering Research, December.

Crafford, Philip L., C. Brand Wessels, and Melanie Blumentritt. 2018. "Sustainability and Wood Constructions: A Review of Green Building Rating Systems and Life-Cycle Assessment Methods from a South African and Developing World Perspective."

Jalaei, Farzad, and Ahmad Jrade. 2014. "Integrating BIM with Green Building Certification System, Energy Analysis, and Cost Estimating Tools to Conceptually Design Sustainable Buildings." Construction Research Congress 2014: Construction in a Global Network - Proceedings of the 2014 Construction Research Congress, 140-49.

Krishnaraj, L., V. R. Prasath Kumar, D. Prerna, R. Senthil Kumar, J. S. Sudarsan, and S. Nithiyanantham. 2021. "Design and Thermal Analysis of the Conventional Residential Building Using Building Information Modeling." Journal of Building Pathology and Rehabilitation 6 (1): 1-10.

Liu, Xin, Qiguang Deng, Shuo Wei, Linlin Meng, and Guanying Cao. 2021. “The Simulation of Indoor Daylight Glare Based on the Location.” Journal of Engineering Research, November.

M. Suliman, Fakher Eldin, and Elfatih A. Elsheikh. 2021. "Thermal Modelling and Simulation of a Laboratory Building for Cooling Energy Consumption.” Journal of Engineering Research 9 (4A). 


\section{Maurya, Amit, Ravinder Kumar, Ujjwal Bharadwaj, Paritosh Rawat, and Mukul} Kumar. 2021. "Sustainable Building Design: Energy Analysis of a Residential Building Using AutodeskRevit." Proceedings of 2021 2nd International Conference on Intelligent Engineering and Management, ICIEM 2021, April, 441-46.

Palme, Massimo, Riccardo Privitera, and Daniele la Rosa. 2020. "The Shading Effects of Green Infrastructure in Private Residential Areas: Building Performance Simulation to Support Urban Planning.” Energy and Buildings 229 (December): 110531. 